\title{
In-Service Teacher Training and Education in Indonesia
}

\author{
Bambang A. Loeneto, E. Ernalida, E. Eryansyah, Zahra Alwi, Santi Oktarina \\ Language Education Department, Faculty of Teacher Training and Education, Sriwijaya University, Palembang, Indonesia \\ Email: loenetobambang@gmail.com, eryansyah@unsri.ac.id, ernalidapurnama@yahoo.co.id, zahra@fkip.unsri.ac.id, \\ santioktarina@yahoo.com
}

How to cite this paper: Loeneto, B. A., Ernalida, E., Eryansyah, E., Alwi, Z., \& Oktarina, S. (2020). In-Service Teacher Training and Education in Indonesia. Creative Education, 11, 328-342.

https://doi.org/10.4236/ce.2020.113026

Received: January 6, 2020

Accepted: March 14, 2020

Published: March 17, 2020

Copyright (c) 2020 by author(s) and Scientific Research Publishing Inc. This work is licensed under the Creative Commons Attribution International License (CC BY 4.0).

http://creativecommons.org/licenses/by/4.0/

\begin{abstract}
This study aimed to find out the implementation of teacher education training programs held by FTTE in preparing teacher training and education in the $21^{\text {ST }}$ century concerning student recruitment, curriculums, teacher students' perception, and challenges the faculty had. The four questions referred to critical thinking skill, collaboration skill, communication skill, and using technology as a tool for learning. The data were obtained through documentation and survey questionnaire. The results of the study showed that there were three systems of recruiting the students, namely National Entrance Selection for State University, National Joint Entrance Selection for Public University, and Public University Entrance Examination. The critical thinking was perceived as vital and essential as it is needed in the workplace. The student respondents seemed not to do it very frequently. In analysing complex problems, investigating questions, evaluating different points of view or sources of information, and drawing appropriate conclusions almost $40 \%$ of the samples applied their critical thinking skills. Many applied their collaboration skill such as working in pairs or small groups to complete a task together, setting goals and creating a plan for their team, creating joint products using contributions from each student, presenting their group work to the class, teacher or others. In communication skills, there were three highest answers recorded, namely created charts, tables or graphs, answering questions in front of an audience, and using media other than a written paper such as posters, video, blogs. On the average, $49.85 \%$ did the skills. Using technology as a tool for learning was applied by $43 \%$. Statistically descriptive, most respondents used social networking services, web search engines, and presentation applications as the three highest skills; they perceived as their excellent skills since they dealt with Facebook, Google search, and MS Power Point application.
\end{abstract}

\section{Keywords}

Types of Entrance Test, Curriculum, Critical Thinking Skills, Collaboration 


\section{Introduction}

The Ministry of Education and Culture has been planning to recruit gradually 100,000 teachers from 2018 to 2024 for state schools to replace those who retire, die or leave the job, as well as to anticipate the growth in student and school numbers. In 2018 Indonesia needed nearly a million new teachers (The Jakarta Post, 2018).

Teacher quality is very important in relation to student learning. Therefore it is very crucial to plan to improve public education. However, the education of public school teachers has been the subject of concern; it has not been a primary focus of standards-based reform efforts. This study is concerned with teacher education training to pave the way to Industrial Revolution 4.0.

The IR4.0 might impact on education, particularly on teachers' knowledge. Future teachers will need to be highly trained in the emerging technologies but also, as importantly, in the values associated with using those technologies. In the future, teachers must not only possess the ability to develop the technology but also to know when and where to use that technology. That kind of thinking is both reflective and interdisciplinary. Schools must reinvent themselves quickly. They need to adapt to the demands of the IR4 and have the obligation to come out of its shell and try to give as many opportunities as possible by creating the adequate contexts for students to be prepared for the future jobs. The problem in the future could not be the lack of employment, but the shortage of skills that the new jobs will demand. In other words, teachers must be critical thinkers, problem solvers, innovators, communicators, and provide value driven leadership. They must be able to see beyond the technology at play to the implications for society for the use of that technology. These traits define the knowledge teacher. They must know the technology but be able to meet and solve all aspects of the challenges engendered by this technology. This kind of leader requires a new approach to education.

How to prepare teachers in the $21^{\text {st }}$ century is the concurring topic that both western and eastern countries consider necessary. In western countries such as the United States and England, teachers are required to meet the needs of how to improve the multi-cultural teaching competency for the growing diverse populations and promoting the pre-service teacher education quality by university-school partnership. Meanwhile, in China, the rural teachers face the challenge how to get continuing professional development and engaging in professional learning community by collaborating with peers and parents. In order to solve the problems, the eastern countries can learn the experiences from western countries, and vice versa. Thus, the question of how to prepare highly qualified teachers in the twenty-first century needs to be raised in the global contexts. 
In the Philippines, particularly in the Philippine Normal University, the teacher education training spends 4 years where in the fourth year the students will conduct a teaching practice at schools. After the graduation, the alumni have to take BLEPT, Board Licenser Examination for Professional Teacher in order to be a teacher. While in Indonesia, the teacher education training also spends 4 years where in the seventh semester the students will conduct a teaching practice at schools. In order to be a teacher, the alumni have to take Program Pendidikan Profesi Guru (Teacher Professional Education Program) for about one year. The program is conducted by the FTTE assigned by the Government.

Indonesia as part of the global world needs to be ready in dealing with challenges of the $21^{\text {st }}$ century, one of which is in education field. In other words, Indonesian education needs to accommodate issues of the $21^{\text {st }}$ century learning so those Indonesian citizens are able to compete in this globalised world. One such factor that determines qualified education is teacher. Therefore it is crucial to prepare pre-service teachers who possess knowledge and skills that are necessary in responding to the challenges of this $21^{\text {st }}$ century.

\section{Research Method}

This study was conducted in the Faculty of Teacher Training and Education, Sriwijaya University, Indonesia.

In general, the objective of this study was to explore how FFTE of Sriwijaya University prepared teacher education training in $21^{\text {st }}$ century. Specifically, this study aimed to

1) describe the students recruitment procedures at the faculty;

2) describe the knowledge the faculty focus on in its curriculums;

3) explore teacher students' perception and response; and

4) explore the challenges that the faculty had in the implementation of teacher education training.

\subsection{Data Collection}

The data were obtained through documentation and survey. The documentation data were related to the rules and regulations applied in the teacher education institutions and all the related documents of the implementation of in-service teacher education. The survey questionnaire was distributed to 140 student samples of the FTTE, Sriwijaya University, Indonesia. The questionnaire was distributed through Google form responded by 86 respondents and the other 54 respondents were given the same questionnaire individually. The following are the discussion and findings of each aspect asked in the questionnaire.

\subsection{Data Analysis}

The obtained data were analysed quantitatively and qualitatively. Qualitative data obtained from the documentation were analyzed based on thematic analysis, while the quantitative data obtained from the survey were analyzed using SPSS. 


\section{Results and Discussion}

\subsection{Results and Discussion of Documentation Data}

\subsubsection{In-Service Education of Teachers in Indonesia Context}

It is of vital importance for teachers to perform their functions effectively and efficiently by having some training in new skills and modern methodology. In-service education is designed for the manpower development of the school system and the educational enterprise as a whole. In Indonesia, the teachers are expected to have a high level of education in line with the high level of education standardized by the government. In other words, there is no level of education being able to be above the quality of its teachers. The Government Regulation No. 14 of 2005 concerning teachers and lecturers states that teachers must have academic qualifications, competencies, educator certificates, physical and spiritual health, and be able to realize national education goals. Besides having undergraduate qualifications, teachers must also have an educator certificate obtained through Teacher Professional Education (PPG). Consequently, it becomes crucial to provide sound in-service education for teachers to update their skills, knowledge and experience in order to meet the growing needs of education in a global economy.

In-service education can simply be defined as the relevant courses and activities in which a serving teacher may participate to upgrade his professional knowledge, skills, and competence in the teaching profession. Therefore, it encompasses all forms of education and training given to a teacher who is already on the job of teaching and learning.

Osamwonyi (2016) points out that the 1976 billing of in-service education is staff development which is a deliberate and continuous process involving the identification and discussion of present and anticipated needs of individual staff for furthering their job satisfaction and career prospects and of the institution for supporting its academic work and plans, and implementation of programmes of staff activities designed for the harmonious satisfaction of these needs.

Generally, the teachers are regarded as the hub of educational development. Therefore, in-service education is concerned with the activities and courses in which a serving teacher may participate for the purpose of upgrading his professional skills, knowledge and interest, subsequent to initial training. In this case, in-service education is designed to fill the gap of professional inadequacies of a serving teacher. As Fisher (2003) has rightly pointed out the skill appropriate for generation ago might no longer prepare students for the world beyond school. Students are being tasked to be more creative and thoughtful in their daily activities.

In-service education is also referred to as continuing education that is designed for the retraining, re-skilling and updating the knowledge of manpower. According to Titmus (1989), adults' lifelong education can be regarded as the entire body of educational processes whatever the content level and method, whether formal or otherwise, whether they prolong or replace initial education 
in schools, colleges and universities as well as in apprenticeship, whereby persons regarded as adults by the society to which they belong develop their abilities, enrich their knowledge, improve their technical or professional qualifications or turn them in a new direction and bring about changes in their attitudes or behaviour in the two fold perspective of full personal development and participation on balance and independent social, economic and cultural development.

Article 20 of the Regulation of the Minister of Education and Culture of Republic of Indonesia No. 37 of 2017 on certification of in-service teachers appointed as public servants at the latest the end of 2015 stipulates that a participant being recruited in the PPG program must be a university undergraduate, in-service teacher appointed public servant at the end of 2015 at the latest, have a Unique Number of Teacher, and be registered in the data base of education of the Ministry of Education and Culture.

As one of the ten faculties at Sriwijaya University, Faculty of Teacher Training and Education (hereinafter abbreviated as FTTE) has the mother university recruited its students. In other words, FTTE does not recruit the students itself; rather Sriwijaya University does the recruitment. Once students are admitted, they will be sent to the faculty and majors they applied based on their interest. Since there are various study programs in the undergraduate degree, students majoring in a study program will be educated and trained in the program until they graduate.

\subsubsection{In-Service Teacher Education Curriculum}

Curriculum is an educational program which states a) the educational purpose of the program (the ends), b) the content, teaching procedures and learning experiences which will be necessary to achieve this purpose (the means), and c) some means for assessing whether or not the educational ends have been achieved (Thompson et al., 2003). A teacher education is fundamentally about educating and preparing pre-service teachers. It follows that one of the duties of the management is to prepare the curriculum based on the need of the stakeholders. This involves considering what lecturers teach and what students learn, how learning is organized and with what success. In order to be successful, aims and objectives of what is intended to be learned, sequence the objectives into a learning sequence, and choose appropriate teaching, learning and assessment methods need to be set. This is what curriculum involves.

According to the Regulation of the Minister of Research, Technology, and Higher Education No. 37 of 2017 Article 20 paragraph (11) PPG Program Study Load is at least 24 (twenty four) credits. Following this Regulation in Article 20 paragraph (6), the PPG In-Service curriculum with a total of 24 credits is broken down into three forms of learning, namely lectures (deepening academic material), workshops, and practical experience in the field (PPL). Academic material includes pedagogic academics and study/professional academics. Pedagogic academic material with the subject matter of Education and Professional Educa- 
tors is directed to provide reinforcement about the basics of education science and teacher principles as a profession. Whereas the subject matter for study/professional academics does not only cover scientific material, but also is related to the way of learning, or is associated with the application of the principle of TPACK (Technological Pedagogical and Content Knowledge).

\subsubsection{Student Recruitment System}

The Regulation of Minister of Research, Technology and Higher Education (2017) stipulates the acceptance of new undergraduate students of Public Universities through three types of higher education student recruitment, firstly, SNMPTN (Seleksi Nasional Masuk Perguruan Tinggi Negeri-National Entrance Selection for State University) in which a public university must accept the matriculants minimum $40 \%$ of its total seats with acceptance selection criteria based on report cards, National Examination scores, and other academic achievements. In addition, the senior high schools accredited A will be accepted 50\% of the best students, those of accredited B will be accepted $25 \%$ of their best students, those of accredited $\mathrm{C}$ will be accepted $10 \%$ of their best students, and those of no accreditation will be accepted $5 \%$ of their best students.

Secondly, SBMPTN (Seleksi Bersama Masuk Perguruan Tinggi Negeri National Joint Entrance Selection for Public University) in which a public university must accept the matriculants minimum $30 \%$ of its total seats. The criteria for acceptance of matriculants use test scores. The written test participants are divided into three groups, namely $I P A$, the natural sciences group, IPS, the social sciences group, and the IPC combination of basic knowledge, IPA, and IPS. This division is based on the requirements of prospective students based on the character of each department. Participants who choose the Natural Sciences and Social Sciences exam path can choose two different majors, while for IPC they can choose three different majors with at least one major in the Natural Sciences or Social Sciences group. The tests cover TPA (Academic Potential Test) and TBSD (Basic Field Study Test covering Basic Mathematics, Indonesian and English on the first day. On the second day, the test takers work on different question groups according to the study program they register. The Natural Sciences group work on Natural Sciences Field Test which includes Mathematics (Physics), Physics, Chemistry, and Biology. Those in the Social Sciences group work on social studies tests covering Economics, Geography, Sociology, and History. As for the IPC group, they work on the Science Study Field Test and the Social Studies Field Test.

Thirdly, UMPTN Ujian Masuk Perguruan Tinggi Negeri, Public University Entrance Examination. The examination is self-managed by a public university for recruiting matriculants about $30 \%$ of its total seats.

\subsubsection{Expected In-Service Teacher Competence}

In any civilization, including Indonesia, teachers' profession has a strategic value because teachers are responsible for a noble duty in the process of humanity, humanization, and the nation character building. This strategic value is accom- 
modated in the acknowledgement of teachers' job as a profession. The issuance of Law No 14/2005 about teacher and lecturer legalizes teachers' job status as a profession.

A teacher is a professional educator whose primary task is to educate, teach, guide, direct, coach, assess, and evaluate students of formal education in early childhood education, primary education, and secondary education (Government Regulation No 19/2005). It is worth saying that teachers play a major role in the development of education. Teachers also determine the students' success, particularly in relation to teaching and learning. In addition, teachers have great influence in shaping the outcome of the education (Sembiring, 2002). Therefore, any attempt made to improve the quality of education would not provide a meaningful contribution without the support of professional and qualified teachers.

In order to contribute to qualified education, teachers should meet the qualification prescribed. Qualified teachers are needed to maximize efficient role of education system and to improve the quality of students' learning. Qualified teachers are claimed to be those who can provide optimal learning outcomes for every learner in the classroom; an outcome considered central to national development (UNESCO, 2014). In line with this, Indonesian government has stipulated the Decree of Ministry of Education and Culture No 16/2007 about the Academic Standard and Competency Qualification that teachers have to fulfil the standard of academic qualifications and competences.

Competence is an underlying characteristic of a person which enables him to deliver superior performance in a given job, role or situation (Marshall, 1996). In other words, competence means a skill and a standard of performance. Teacher competences have been investigated to increase the quality of teaching and teacher education. Studies by Lake (2014); Arikan, Tager \& Sarac-Suzer (2008) indicate that teacher competence correlated with the students' success.

According to Indonesian Government Regulation No 19/2005 about the Standard of National Education, teachers have to possess four basic competences, viz: professional competence, pedagogical competence, personal competence, and social competence. Professional competence is related to their mastery of the subject matter. Pedagogical competence is associated with their knowledge of instructional design and teaching practices. Personal competence is linked to the teachers' personality in carrying out their profession as teachers. Social competence is concerned with their ability to socialize with the schools and stakeholders.

\subsubsection{Meta Knowledge}

Meta knowledge refers to knowledge of the process of working with foundational knowledge. This could also be seen in terms of three subcategories: Problem Solving and Critical Thinking, Communication and Collaboration, and Creativity \& Innovation.

Problem Solving and Critical Thinking 
Critical thinking frequently involves the ability to interpret information and make informed decisions based on such information. Problem solving is often conceptualized as the use of (critical thinking skills toward the effective resolution of a specific problem or toward a specific end goal. Problem solving and critical thinking most often involve the cognitive skills necessary for success in emerging economic and social domains.

Communication and Collaboration

Communication most frequently involves the ability to clearly articulate oneself through all media of communication-oral, written, nonverbal, and digital-as well as the skills necessary to be an active and respectful listener to diverse audiences. Collaboration includes similar dimensions as communication but also includes important individual contributions, such as flexibility willingness to participate, and recognition of group and individual efforts and success. Communication and collaboration are cited as essential to success in the $21^{\text {st }}$ century as working with diverse groups becomes of the utmost importance in our increasingly globalized culture and economy.

Creativity and Innovation

Creativity was one of the skills that was most cited as necessary for success in the $21^{\text {st }}$ century. Creativity and innovation involve applying a wide range of knowledge and skills to the generation of novel and worthwhile products (tangible or intangible) as well as the ability to evaluate, elaborate, and refine ideas and products. It is often reasoned that the highly complex problems facing society in the $21^{\text {st }}$ century necessitate new and creative solutions.

\subsubsection{Implications for Teachers and Teacher Educators}

This framework provides some specific recommendations for teachers and teacher educators. In brief, we point to three key suggestions. First, disciplinary knowledge and domain knowledge are as important as ever and will continue to be so well into the foreseeable future. Educational systems remain fundamentally based on disciplinary knowledge and, as such, require teachers to be adequately trained and proficient in the disciplines. The advancement of the Common Core State Standards not only maintains a focus on disciplinary knowledge, but also appreciates the importance of students as critical thinkers with the ability to analyse information in the execution of daily tasks (NGA Centre, 2010). The need for students to develop deep disciplinary knowledge has always been important; what has changed is access to disciplinary knowledge and authentic disciplinary inquiry made available through technology and subsequently experts and resources. Although some may argue that there is a divide between those promoting these types of $21^{\text {st }}$ century skills and the structure of the Common Core State Standards, meaningful alignments exist between the two. For example, the 4 C's (critical thinking and problem-solving, creativity and innovation, communication, and collaboration) are represented throughout the standards. Students and teachers must work in purposeful learning communities, engage with questions that require reflection, defend conclusions and problem-solve 
like detectives while responding like investigative reporters. Therefore, the current base of disciplinary knowledge that the Common Core expresses encompasses both traditional content knowledge and concepts forwarded in modern frameworks, such as students having strong communication skills integrated across content areas, being metacognitive in an iterative process, engaging with complex texts and complex problem solving, and developing a world focus.

Second, knowing the technology is important, but knowing when and why to use it is more important. This is closely related to the TPACK framework and knowledge that teachers must possess to teach effectively with technology (Mishra \& Koehler, 2006). However, it is distinctly different in that the TPACK framework is admittedly content neutral and pedagogically neutral. In sharp contrast, this framework identifies and places great emphasis on the foundational knowledge that students and teachers must possess. That being said, basic digital literacy skills are essential for both students and teachers. Knowing when to use a particular technology for activities such as collaboration, or why to use a certain technology for acquiring specific disciplinary knowledge, is a vastly more important, transferable, infinitely relevant type of knowledge, one that will not quickly become antiquated with ever-changing technological trends.

Third, technological advances of the $21^{\text {st }}$ century have brought us closer together and at the same time further apart. Advances to technology and infrastructure have made physical proximity optional, not only in education, but also in fields such as business and medicine, and they have made availability for interaction effortless. As a result of the increased opportunity for interaction across countries and around the world, teachers need to know how to foster cultural competence, emotional awareness, and leadership skills to facilitate not just interactions, but meaningful interactions and relationships. Interestingly, this specific type of knowledge is largely absent of the standard-based movements in education and not always seen as worthy of prolonged instructional time and effort.

\subsection{Results and Discussion of Questionnaire Data}

\subsubsection{Critical Thinking Skill}

This skill referred to students being able to analyze complex problems, investigate questions for which there were no clear-cut answers, evaluated different points of view or sources of information, and drew appropriate conclusions based on evidence and reasoning. The students showed that more than $50 \%$ frequently did the critical thinking skill as part of their classroom activities, and more than $25 \%$ always did it (see Table 1 ).

\subsubsection{Collaboration Skill}

The skill referred to students being able to work together to solve problems or answer questions, to work effectively and respectfully in teams to accomplish a common goal and to assume shared responsibility for completing a task.

In their learning activities, the respondents demonstrated through working in pairs or small groups to complete a task together, working with other students to 
Table 1. Descriptive statistics of critical thinking skill.

\begin{tabular}{lccccc}
\hline $\begin{array}{l}\text { In your language learning in the class, how } \\
\text { often have you been asked to do the } \\
\text { following }\end{array}$ & Always & Often & $\begin{array}{c}\text { Not } \\
\text { Know }\end{array}$ & Seldom & Never \\
\hline $\begin{array}{l}\text { Compare information from different } \\
\text { sources before completing a task or } \\
\text { assignment? }\end{array}$ & $39.00 \%$ & $53.57 \%$ & $0.00 \%$ & $7.14 \%$ & $0,00 \%$ \\
$\begin{array}{l}\text { Draw your own conclusions based on } \\
\text { analysis of numbers, facts, or relevant } \\
\text { information? }\end{array}$ & $26.42 \%$ & $70.71 \%$ & $1.43 \%$ & $1.43 \%$ & $0,00 \%$ \\
& & & & & \\
\hline $\begin{array}{l}\text { Summarize or create your own } \\
\text { interpretation of what you have read } \\
\text { or been taught? }\end{array}$ & $35.71 \%$ & $62.85 \%$ & $0.71 \%$ & $0.71 \%$ & $0,00 \%$ \\
$\begin{array}{l}\text { Analyze competing arguments, perspectives } \\
\text { or solutions to a problem? }\end{array}$ & $40.00 \%$ & $55.00 \%$ & $1.43 \%$ & $2.14 \%$ & $1,43 \%$ \\
$\begin{array}{l}\text { Develop a persuasive argument based on } \\
\text { supporting evidence or reasoning? }\end{array}$ & $8.57 \%$ & $45.00 \%$ & $7.85 \%$ & $38.57 \%$ & $0,00 \%$ \\
$\begin{array}{l}\text { Try to solve complex problems or answer } \\
\text { questions that have no single correct } \\
\text { solution or answer? }\end{array}$ & $10.71 \%$ & $30.71 \%$ & $2.85 \%$ & $30.71 \%$ & $3,57 \%$ \\
\hline & $26,74 \%$ & $52.97 \%$ & $2.38 \%$ & $13.45 \%$ & $0.83 \%$ \\
\hline
\end{tabular}

set goals and create a plan for their team, creating joint products using contributions from each student, presenting their group work to the class, teacher or others, working as a team to incorporate feedback on group tasks or products, and giving feedback to peers or assess other students' work. There were almost $40 \%$ of the students always doing the skills, and more than $50 \%$ frequently doing the skills. A complete result is summarized in Table 2.

\subsubsection{Communication Skill}

The skill referred to students being able to organize their thoughts, data and findings and share these effectively through a variety of media, as well as orally and in writing.

In responding to the question of how often the respondents were asked to do structuring data for use in written products or oral presentations such as creating charts, tables or graphs, conveying their ideas using media other than a written paper for examples, posters, video, blogs, etc., preparing and delivering an oral presentation to the teacher or others, answering questions in front of an audience, and deciding how they would present their work or demonstrate their learning, $72.85 \%$ always and $26.85 \%$ often did them respectively and only $0.14 \%$ seldom or never did them (Figure 1).

\subsubsection{Using Technology as a Tool for Learning}

Using technology as a tool for learning referred to students being able to manage their learning and produce products using appropriate information and communication technologies (Table 3). 
Table 2. Descriptive statistics of collaboration skills.

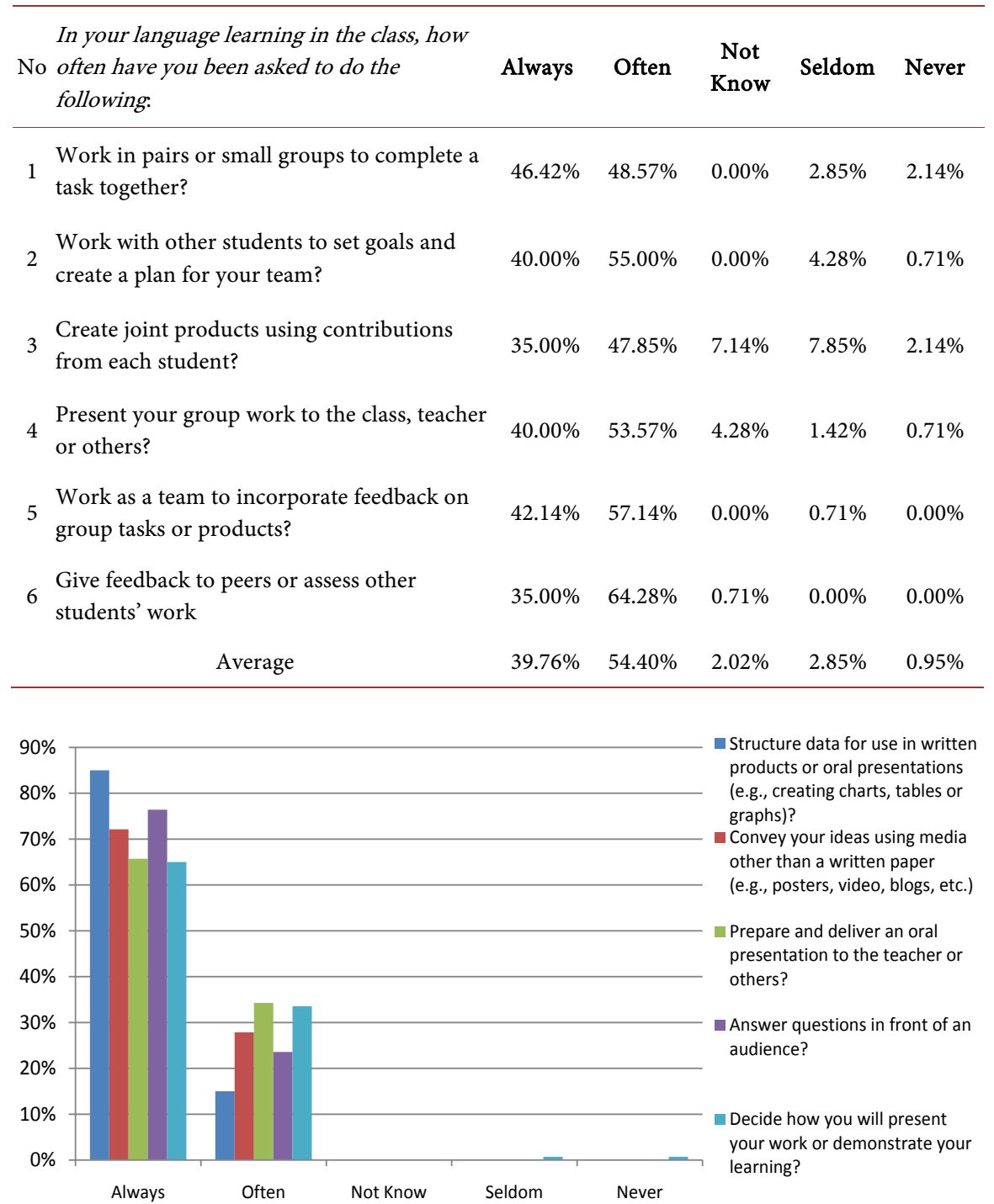

Figure 1. Descriptive statistics of communication skills.

\section{Discussion}

This study responded to the need to evaluate the impact of technology-enhanced instruction within classrooms. The purpose of this study was, among others, to analyze how pre-service teacher education training use technology as a tool for their learning and development of 21st-century skills, and how they apply those skills in classrooms. Though critical thinking has been perceived as vital and essential as it is needed in the workplace, the study found that the student respondents seemed not to be aware that they themselves did not do it very frequently. More than 30\% seldom developed a persuasive argument based on supporting evidence or reasoning and tried to solve complex problems or answer questions that have no single correct solution or answer. Duron, Limbic \& Waugh (2006) state that a critical thinking skill can assist trainee teacher to be in contact with 
Table 3. Descriptive statistics of using technology as a tool for learning.

\begin{tabular}{|c|c|c|c|c|c|c|}
\hline No. & $\begin{array}{l}\text { In your language learning in the class, how } \\
\text { often have you been asked to do the following: }\end{array}$ & Always & Often & $\begin{array}{c}\text { Not } \\
\text { Know }\end{array}$ & Seldom & Never \\
\hline 1 & $\begin{array}{l}\text { Use technology or the Internet for } \\
\text { self-instruction (e.g., Kahn Academy or other } \\
\text { videos, tutorials, self-instructional } \\
\text { websites, etc.)? }\end{array}$ & $47.14 \%$ & $42.14 \%$ & $0.00 \%$ & $10.71 \%$ & $0.00 \%$ \\
\hline 2 & $\begin{array}{l}\text { Select appropriate technology tools or } \\
\text { resources for completing a task? }\end{array}$ & $43.57 \%$ & $51.42 \%$ & $0.00 \%$ & $0.05 \%$ & $0.00 \%$ \\
\hline 3 & $\begin{array}{l}\text { Evaluate the credibility and relevance of online } \\
\text { resources? }\end{array}$ & $25.71 \%$ & $29.28 \%$ & $22.85 \%$ & $4.28 \%$ & $3.57 \%$ \\
\hline 4 & $\begin{array}{l}\text { Use technology to analyze information (e.g., } \\
\text { databases, spreadsheets, graphic programs, } \\
\text { etc.)? }\end{array}$ & $67.85 \%$ & $26.42 \%$ & $0.00 \%$ & $5.71 \%$ & $0.00 \%$ \\
\hline 5 & $\begin{array}{l}\text { Use technology to help them share information } \\
\text { (e.g., multi-media presentations using sound or } \\
\text { video, presentation software, blogs, podcasts, } \\
\text { etc.)? }\end{array}$ & $40.71 \%$ & $57.85 \%$ & $0.00 \%$ & $1.43 \%$ & $0.00 \%$ \\
\hline 6 & $\begin{array}{l}\text { Use technology to support team work or } \\
\text { collaboration (e.g., shared work spaces, email } \\
\text { exchanges, giving and receiving feedback, etc.)? }\end{array}$ & $79.28 \%$ & $17.14 \%$ & $0.00 \%$ & $3.57 \%$ & $0.00 \%$ \\
\hline 7 & $\begin{array}{l}\text { Use technology to interact directly with experts } \\
\text { or members of local/global communities? }\end{array}$ & $73.57 \%$ & $23.57 \%$ & $0.00 \%$ & $2.85 \%$ & $0.00 \%$ \\
\hline 8 & $\begin{array}{l}\text { Use technology to keep track of your work on } \\
\text { extended tasks or assignments? }\end{array}$ & $40.00 \%$ & $43.57 \%$ & $0.00 \%$ & $15.71 \%$ & $0.71 \%$ \\
\hline 9 & $\begin{array}{l}\text { Use online or installed application to improve } \\
\text { your language skills (Google Translate, } \\
\text { Grammarly, Mendeley, Plagiarism Checker, } \\
\text { Electronic Dictionary) }\end{array}$ & $91.40 \%$ & $7.85 \%$ & $0.00 \%$ & $0.71 \%$ & $0.00 \%$ \\
\hline 10 & $\begin{array}{l}\text { Make an academic website, blog, or application } \\
\text { to solve a given problem or perform a } \\
\text { specific task }\end{array}$ & $15.00 \%$ & $24.28 \%$ & $0.05 \%$ & $54.28 \%$ & $0.00 \%$ \\
\hline 11 & $\begin{array}{l}\text { Protect your own data using the current } \\
\text { technology }\end{array}$ & $70.71 \%$ & $25.71 \%$ & $1.43 \%$ & $1.43 \%$ & $0.71 \%$ \\
\hline
\end{tabular}

their cognitive abilities and "spiritual questions, and it can be used to evaluate people, policies, and institutions, thereby avoiding social problems."

As we know, the critical thinking in the educational settings is embedded in the work of Bloom (1956). Teachers have discussed and employed the taxonomy in their work. They teach and evaluate "higher order thinking skills" using Bloom's taxonomy. The taxonomy in the categories of analysis, evaluation, and creating are in the highest level are signifies critical thinking, while comprehension is at the bottom and the top. Lai (2011) and Ennis (2009) similarly state that the higher three levels of Bloom's taxonomy of educational objectives (analysis, evaluation, and creating) are often defined as critical thinking.

Collaborative learning refers to any instructional method in which students work together toward a common goal, emphasising interaction and group proc- 
esses (Prichard, Stratford, \& Bizo, 2006). Collaborative learning strategies are less specific and not easy to define, since they include a broad scope of strategies that are not necessarily systematic or prescriptive (Rose, 2004). In this study, more than $50 \%$ of student teachers applied their collaboration skill such as working in pairs or small groups to complete a task together, setting goals and creating a plan for their team, creating joint products using contributions from each student, presenting their group work to the class, teacher or others, working as a team to incorporate feedback on group tasks or products, and giving feedback to peers or assess other students' work. Yet, Rose (2004) argues that collaborative learning strategies are less specific and not easy to define since they include a broad scope of strategies that are not necessarily systematic or prescriptive. In contrast, Dillenbourg (1999) and Slavin R. E. (1985) state that particular forms of interaction between team members, such as asking questions, debating, and explaining, encourage active and purposeful knowledge construction and ensure that everyone in the group benefits from working together.

In communication skills, five questions were asked if the student respondents created charts, tables or graphs, used media other than a written paper such as posters, video, blogs, preparing and delivering an oral presentation to the teacher or others, answering questions in front of an audience, and presenting the work or demonstrating their learning. There were three highest answers recorded, namely created charts, tables or graphs, answering questions in front of an audience, and using media other than a written paper such as posters, video, blogs. Above all, teachers must have the ability to communicate their subject-matter expertise to facilitate classroom learning and participation. Students depend on their teachers to provide them with instruction, guidance and feedback throughout the learning process. When a teacher fails to communicate effectively with students, their comprehension level drops, and they eventually lose grasp of the subject matter. As time goes on, students' academic progress may suffer from not receiving the proper support in fundamental subjects. Fundamental to teacher and student success is the teacher's ability to communicate effectively with students, parents and colleagues. Teachers must have good communication skills to help their students achieve academic success. Teachers also need good communication skills to further their careers in education. Without good communication skills, teachers disable the learning process as well as their own career mobility.

Technology merely provides the tools to be used for authentic learning. It is a means, not an end. Technology provides teachers with the opportunity to move from simply streamlining the way things have always been done to really imagining things they would like to do. The data showed that most student respondents applied it in their classroom activities.

The data of this study showed that the descriptive statistics on how the respondents perceived their skills in using some tools for learning. Social networking services, Web search engines, and Presentation applications were the three highest skills the student respondents perceived as their excellent skills 
since they dealt with Facebook, Google search, and MS Power Point application. Meanwhile, applying the Word processing applications such as Microsoft Word was perceived as good.

\section{Conclusion and Suggestion}

The current study investigated in-service teachers' competence levels of 21 st-Century skills paving the way to IR 4.0 and how they apply their competence in their classroom environment. This study responded to the need to evaluate the impact of technology-enhanced instruction within classrooms. Though critical thinking has been perceived as vital and essential as it is needed in the workplace, the study found that the student respondents seemed not to be aware that they themselves did not do it very frequently. They seldom developed a persuasive argument based on supporting evidence or reasoning and tried to solve complex problems or answer questions that have no single correct solution or answer.

In collaboration skill, many student teachers applied their collaboration skill such as working in pairs or small groups to complete a task together, setting goals and creating a plan for their team, creating joint products using contributions from each student, presenting their group work to the class, teacher or others, working as a team to incorporate feedback on group tasks or products, and giving feedback to peers or assess other students' work.

In communication skills, there were three highest answers recorded, namely created charts, tables or graphs, answering questions in front of an audience, and using media other than a written paper such as posters, video, blogs. Fundamental to teacher and student success is the teacher's ability to communicate effectively with students, parents and colleagues.

In using technology as a tool for learning, most of the student respondents applied it in their classroom activities. Statistically descriptive most respondents used social networking services, web search engines, and presentation applications as the three highest skills; they perceived as their excellent skills since they dealt with Facebook, Google search, and MS Power Point application. Meanwhile, applying the Microsoft Word was perceived as good.

For future research, it is suggested that the study involve some teachers to participate in classroom observation to facilitate the teaching of 21st-Century skills alongside content-specific subjects as a good baseline study for teachers' competence and skills in integrating ICT into their classroom activities. In addition, teachers must have the support of all stakeholders in the educational community in order to successfully infuse technology into their classrooms. They must resist the notion that learning to use the gadgets is an end in itself. Teachers must educate themselves on how to best use those tools to enhance teaching and learning.

\section{Conflicts of Interest}

The authors declare no conflicts of interest regarding the publication of this paper. 


\section{References}

Arikan, A., Tager, D., \& Sarac-Suzer, H. S. (2008). The Effective English Language Teacher from the Perspective of Turkish Preparatory School Students. Education and Science, 33, 42-51.

Bloom, B. S. (Ed.) (1956). Taxonomy of Educational Objectives. Vol. 1: Cognitive Domain. New York: McKay.

Dillenbourg, P. (Ed.). (1999) Collaborative-Learning: Cognitive and Computational Approaches (pp. 1-19). Oxford: Elsevier.

Duron, R., Limbach, B., \& Waugh, W. (2006). Critical Thinking Framework for Any Discipline. International Journal of Teaching and Learning in Higher Education, 17, 160-166.

Ennis, R. H. (2009). Critical Thinking Assessment. Journal of Theory into Practice, 32, 179-186. https://doi.org/10.1080/00405849309543594

Lai, E. R. (2011). Critical Thinking: A Literature Review. Research Report. https://images.pearsonassessments.com/images/tmrs/CriticalThinkingReviewFINAL.p df

Lake, B. (2014). Secondary School Teachers' Competence in Educational Assessment of Students in Bahir Dar Town. Bahir Dar Journal of Education, 14, 54-63.

Marshall, P. (1996). Why Are Some People More Successful than Others? In N. Boulter, D. Murray, \& J. Hill (Eds.), People and Competencies (2nd ed.). London: Kogan Page.

Mishra, P., \& Koehler, M. J. (2006). Technological Pedagogical Content Knowledge: A New Framework for Teacher Knowledge. Teachers College Record, 108, 1017-1054. https://doi.org/10.1111/j.1467-9620.2006.00684.x

Osamwonyi, E. F. (2016). In-Service Education of Teachers: Overview, Problems and the Way Forward. Journal of Education and Practice, 7, 83-87.

Prichard, J. S., Stratford, R. J., \& Bizo, L. A. (2006). Team-Skills Training Enhances Collaborative Learning. Journal of Learning and Instruction, 16, 256-265. https://doi.org/10.1016/j.learninstruc.2006.03.005

Rose, M. A. (2004). Comparing Productive Online Dialogue in Two Group Styles: Cooperative and Collaborative. American Journal of Distance Education, 18, 73-88. https://doi.org/10.1207/s15389286ajde1802_2

Sembiring, M. G. (2002). Mengungkap rahasia dan tips manjur menjadi guru sejati. Yogyakarta: Galangpress.

Slavin, R. E. (1985). Cooperative Learning: Applying Contact Theory in Desegregated Schools. Journal of Social, 3, 45-62.

The Jakarta Post (2018). https://www.thejakartapost.com/news/2018/06/07

Thompson, S. D., Martin, L., Richards, L., \& Branson, D. (2003). Assessing Critical Thinking and Problem Solving Using a Web-Based Curriculum for Students. The Internet and Higher Education, 6, 185-191. https://doi.org/10.1016/S1096-7516(03)00024-1

Titmus, C. J. (1989). Lifelong Education for Adults: An International Handbook. Oxford: Pergamon Press plc. England.

UNESCO (2014). EFA, Global Monitoring Report. Paris: UNESCO. 